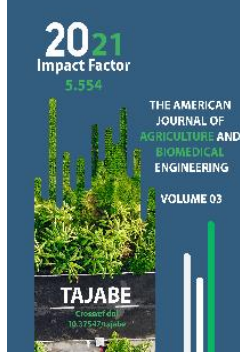

Journal Website: https://theamericanjou rnals.com/index.php/ta jabe

Copyright: Original content from this work may be used under the terms of the creative commons attributes 4.0 licence.

\section{Effect Of Sowing Norms On Biometric Indicators, Yield And Grain Quality Parametres Of Darmon Variety Of Lentil Sown In Autumn And Spring}

\author{
Kurbonov A.A. \\ Researcher Of Tashkent State Agrarian University, Uzbekistan \\ Atabayeva H.N. \\ Professor Of Tashkent State Agrarian University, Uzbekistan \\ Khayrullayev S.Sh. \\ Ph.D Student Of Tashkent State Agrarian University, Uzbekistan
}

\title{
ABSTRACT
}

This article provides information on the effect of sowing 2.0, 3.0, 4.0 million germinated seeds of lentils "Darmon" in autumn and spring on the biometric parameters of the plant. In Darmon variety of lentils, the height of the stem was $51.1-58.8 \mathrm{~cm}$ in autumn, $43.7-52.2 \mathrm{~cm}$ in spring, the leaf area was $23.2-35.8$ thousand $\mathrm{m} 3$ in autumn and 22.2-33.7 thousand $\mathrm{m} 3$ in spring. As a result of symbiotic activity, the weight of nodules in the autumn was 3.17-4.52 c/ ha, in the spring - 2.82-3.98 c/ ha, and per thousand grains - 78.9 -81.9 grams in the autumn and 78.5-81.1 grams in the spring. It was found that as the number of seedlings increased, the weight of thousands of grains on the options decreased due to lack and high demand of nutrients. The same pattern was observed in the location of the first pod in both periods, but in the spring due to external factors the location of the lower pod was slightly higher, the yield in the autumn was 24.3-27.4 C / ha, and in the spring -17.1-20.3 c/ ha, and the best result was found to be obtained when seeds were sown on 3 million pieces/ha.

\section{KEYWORDS}

Sowing dates, sowing norms, "Darmon”, biometric indicators, yield, grain quality.

\section{INTRODUCTION}

Along with cereals, legumes also play an important role in improving the supply of nutritious, high-quality food required for the needs of the population. Cereals are richer in protein, essential amino acids, and vitamins than whole grains, and their grains contain 25- 
The American Journal of Agriculture and Boimedical Engineering

(ISSN - 2689-1018)

IMPACT FACTOR

Published: August 31, 2021| Pages: 9-13

Doi: https://doi.org/10.37547/tajabe/Volume03Issue08-02

2021: 5.554

OCLC - 1121105746

$50 \%$ protein. Lentils play an important role among cereals. Because lentils are one of the oldest food crops, the grain contains $23-32 \%$ protein, $0.6-2.1 \%$ fat, $47-70 \%$ nitrogen-free extractives, $2.3-4.4 \%$ ash, $2,4-4.9 \%$ tissue and B vitamins. Lentils are used whole, as a cereal or flour. The stem contains $6-14 \%$ protein. Lentils increase soil fertility due to being a legume crop. Lentils are a very productive crop, and their grains are almost equal in nutrition to beef [6].

The degree to which the problem has been studied - Many scientists have found that the planting dates of lentils vary from country to country, depending on soil-climatic conditions and the biological characteristics of the variety. Planting of lentils begins when the temperature in the top $10 \mathrm{~cm}$ layer of soil reaches $+120 C[1,4]$.

Lentils are planted in autumn and spring after cereals (wheat, barley, corn), potatoes, root crops, vegetables. Lentils are planted in sowing machines sown with cereals and alfalfa. 60-120 $\mathrm{kg}$ of seeds are used per hectare. Planting depth is $4-6 \mathrm{~cm}[9,5]$.

Planting rate and depth are important in disorderly and flattening. Therefore, in areas where lentils are planted, seeds that are not sown at the same depth can become diseased and rot due to increased moisture and lack of heat in the soil. This in turn leads to a decrease in the number of plant bushes and has a negative impact on productivity [1].

According to Kurbanov A.A, Kh.N.Atabayeva, and S.Sh.Khayrullaev, the thickness of seedlings of lentils "Oltin don" and "Darmon" planted in autumn and spring has a significant impact on its growth, development and yield, reaching 3 million seedlings per hectare, and sowing at the expense of germinated seeds provides an increase in yield [2].

\section{MATERIALS AND METHODS}

Our research was conducted in 2011-2013 in the fields of the experimental plot of the Tashkent State Agrarian University. The soil of the experimental field is a typical sierozem, which has been irrigated for a long time, the mechanical composition is sandy, the groundwater is located at a depth of 15-18 meters.

In our research, the effect of sowing lentil varieties "Oltin don" and "Darmon" in autumn and spring at the rate of 2.0, 3.0, 4.0 million seeds per hectare on the dry mass of the plant was studied.

The research was conducted in the field and in the laboratory, including the placement of field experiments, calculations and observations "Methods of field experiments" (T. UzPITI 2007), "Methods of field experiments (B. Dospekhov, 1985) and" Methods of State Variety Testing of Agricultural Crops " (1985) based on methodological guidelines $[3,7,8]$.

\section{RESULT AND DISCUSSION}

The fact that the plant grows at a height typical of the planted variety biology means that the cultivation technology is carried out correctly and a high yield is formed.

It was found that the cultivation of lentils "Darmon" in three different dates and in different doses affected their growth. 
When Darmon variety of lentils were planted in autumn, the height of the stems increased as the sowing rate increased. When the sowing norm was 2 million pieces, the stem height was $51.1 \mathrm{~cm}$. When the planting rate was increased to 3 and 4 million, the stem height was 54.7 and $58.8 \mathrm{~cm}$, respectively, an increase of $3.6 ; 7.7 \mathrm{~cm}$ or $6.6 ; 13.1 \%$ compared to the first option. The same pattern was observed when this variety was planted in the spring. The height of the stem was 43.7-52.2 cm according to the norms, and it was observed that the height of the stem increased with the increase of the planting norm.

Sowing norms and dates also had a good effect on the leaf surface of the Darmon variety. When this variety was planted in the autumn, the leaf area increased as the sowing rate increased. When the sowing rate was 2 million, the leaf area was 23.2 thousand $\mathrm{m} 3$ / ha, while when this figure was increased to 3 and 4 million, it was 29.6 and 35.8 , respectively. It was found that the leaf area gave a higher result of $6.4,12.6$ thousand $\mathrm{m}_{3} / \mathrm{ha}$ (21.6, 35.2\%) compared to the first option. The same pattern was repeated when planted in the spring period, but it was observed that the leaf area was slightly lower than in the autumn period.

We know that one of the peculiarities of legumes is the implementation of a symbiotic process in the presence of endogenous bacteria in their roots. As a result of this symbiosis process, environmentally friendly biological nitrogen accumulates and increases soil fertility. When we planted Darmon lentils in the autumn at the rate of 2 million units / ha, $3.17 \mathrm{c} /$ ha of endogenous bacteria were formed. This figure was $3.98 \mathrm{c} /$ ha when we increased the sowing rate to 3 million. As the planting rate increased, the number of endogenous bacteria also increased and reached $4.52 \mathrm{c} /$ ha when planted at 4 million units / ha, which greatly contributed to the increase in soil fertility. The same pattern was observed when sowing the Darmon variety of lentils in the spring, i.e. they were $2.82-3.98 \mathrm{c} /$ ha, respectively. However, more endogenous bacteria were formed in the autumn than in the spring.

Also, Sowing date and norms also affected the Darmon variety per 1,000 grain weight. At the same time, when sown in the autumn, this figure gave a slightly higher result (81.9 g), when the sowing rate was raised to 3 million, the weight of one thousand grains was 80.2 grams. When the sowing rate was increased to 4 million, the figure was 78.9 grams. The weight of a thousand grains decreased as the planting rate increased, as the number of seedlings increased as the amount of nutrients the plant assimilated decreased. The same pattern is maintained when planted in the spring term. However, the result was slightly lower than in the autumn.

In addition, the date and norms of planting also affected the height of the first pod of the Darmon variety. The height of the first pod was $19.8 \mathrm{~cm}$ in the variant in which 2 million seedlings were planted per hectare in the autumn. It was found that when the planting rate was increased by 3 million, this figure was $22.8 \mathrm{~cm}$ due to an increase in the number of seedlings and $23.3 \mathrm{~cm}$ when the number of seedlings was increased by 4 million, and the first pod was higher due to an increase in the number of seedlings. The same pattern was observed when the Darmon variety was planted in the spring. However, due to the lack 
of biological factors necessary for the plant in the spring period (humidity, beneficial temperature and etc.) and the inability to form the first pods, the location of the first pods is slightly higher than in the autumn period.

Table 1

Effect of sowing norms on biometric indicators, yield and grain quality parameters of "Darmon" variety of lentil sown in autumn and spring (2011-2013, average)

\begin{tabular}{|c|c|c|c|c|c|c|c|c|}
\hline \multirow[b]{2}{*}{ № } & \multicolumn{2}{|c|}{ Options } & \multicolumn{6}{|c|}{ Biometrical indicators and yield and its quality parameters } \\
\hline & Cultivar & 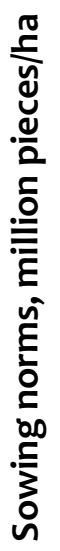 & 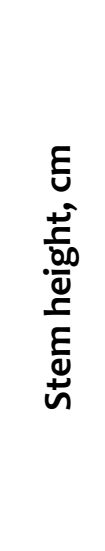 & 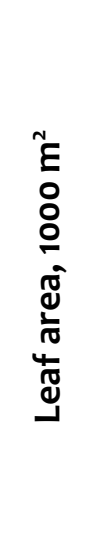 & 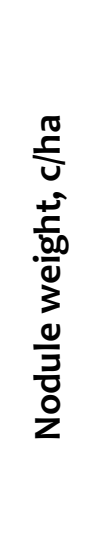 & 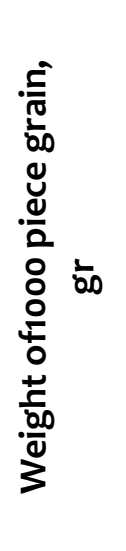 & 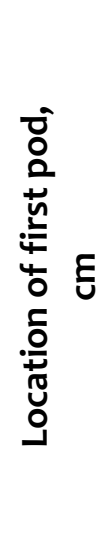 & 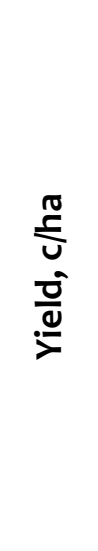 \\
\hline \multicolumn{9}{|c|}{ Sown in autumn } \\
\hline 1 & Darmon & 2 & 51.1 & 23,2 & 3,17 & 81,9 & 19,8 & 24,3 \\
\hline 2 & Darmon & 3 & 54.7 & 29,6 & 3,98 & 80,2 & 22,8 & 27,4 \\
\hline 3 & Darmon & 4 & 58.8 & 35,8 & 4,52 & 78,9 & 23,3 & 26,2 \\
\hline \multicolumn{9}{|c|}{ Sown in spring } \\
\hline 1 & Darmon & 2 & 43,7 & 22,2 & 2,82 & 81,1 & 20,0 & 17,1 \\
\hline 2 & Darmon & 3 & 47,8 & 27,4 & 3,56 & 79,8 & 23,0 & 20,3 \\
\hline 3 & Darmon & 4 & 52,2 & 33,7 & 3,98 & 78,5 & 23,5 & 19,5 \\
\hline
\end{tabular}

Finally, it should be noted that the date and norm of sowing also affected the yield of the Darmon variety of lentils. When we sowed the Darmon variety on 2 million hectares in the autumn, the grain yield was $24.3 \mathrm{c} / \mathrm{ha}$. When the sowing rate was increased to 3 million, the grain yield was $27.4 \mathrm{c} /$ ha, which was $3.1 \mathrm{c} /$ ha (11.3\%) higher than the first option. When the 
sowing rate was increased to 4 million, the yield was $26.2 \mathrm{c} / \mathrm{ha}$, which was $1.9 \mathrm{c} / \mathrm{h}$ ha higher than the control variant, i.e. $7.3 \%$ higher, and 1.2 $\mathrm{c} /$ ha $(4.4 \%)$ lower than the second variant. The best results were obtained when the Darmon variety was planted at 3 million units / ha. A similar pattern was observed when the same options were planted in the spring, with high yields when planted on 3 million units. However, when planted in the spring, the yield was slightly lower than in the autumn planting options (Table 1).

\section{CONCLUSION}

In summary, planting norms have affected the biometric performance of the Durdona variety of lentils.

1. In Darmon variety of lentils, stem height was $51.1-58.8 \mathrm{~cm}$ in autumn and 43.7-52.2 $\mathrm{cm}$ in spring, and the height of stems increased with sowing norms;

2. When the sowing rate was increased from 2 million to 4 million, the leaf area was 23.235.8 thousand $\mathrm{m} 3$ in autumn, 22.2-33.7 thousand $\mathrm{m} 3$ in spring and the same pattern was observed in spring, but slightly less than in autumn;

3. As a result of symbiotic activity in the Darmon variety, it was found that in the autumn period it was $3.17-4.52 \mathrm{c} / \mathrm{ha}$, and in the spring period it was $2.82-3.98 \mathrm{c} / \mathrm{ha}$, and the number of nodules increased with increase the number of seedlings;

4. It was found that the sowing date and norm affected the weight of lentils per thousand grains, 78.9 -81.9 grams in autumn and 78.5-81.1 grams in spring, and the number of seedlings decreased due to malnutrition;
5. It was found that the same pattern was observed in the autumn and spring period, affecting the location of the first pod, but the location of the lower pod was slightly higher in the spring due to external environmental factors;

6. Darmon variety was found to have a yield of 24.3-27.4 C / ha in the autumn and 17.1$20.3 \mathrm{c} / \mathrm{ha}$ in the spring, and the best results were obtained when planted on 3 million pieces / hectares.

\section{REFERENCES}

1. Atabayeva H.N, Khudoykulov J.B. Plant Science. T. Science and technology. 2018, 212 pp.

2. Kurbanov, A. A., Kh N. Atabayeva, and S. Sh Khayrullaev. "Influence of sowing dates and norms on harvest of lentils varieties." ACADEMICIA: An International Multidisciplinary Research Journal 10.10 (2020): 1343-1348.

3. Methods of conducting field experiments UzPITI, Tashkent. 2007.180 p.

4. http/ru.wikisource.org/wiki. 2008.

5. www.olegmaskalev.ru. 2001.

6. Атабаева Х.Н., Умарова Н.С.Растениеводство.Т.2016, 167-169 с.

7. Методика Государственного сортоиспытания сельскохозяйственных культур. -М.: Колос. 1964. 184 с.

8. Доспехов Б.А. Методика полевого опыта. 5-ое изд. доп. и перераб. Агропромиздат. -Москва, 1985. -С.248-256.

9. Посыпанов Г.С.-Растениеводство М.Колос, 1997. 